\title{
Actual Arm Code
}

National Cancer Institute

\section{Source}

National Cancer Institute. Actual Arm Code. NCI Thesaurus. Code C117449.

A character or string that represents the actual arm of a trial or study. 